Fakultas Hukum, Universitas Lampung, Bandar Lampung, Lampung, Indonesia. http://jurnal.fh.unila.ac.id/index.php/corruptio

Volume 01 Issue 2, July-December 2020. PP: 117-128

P-ISSN: 2723-2573

E-ISSN: 2745-9276

\title{
Penanggulangan Tindak Pidana Korupsi, Kolusi Dan Nepotisme Dalam Pengadaan Barang Dan Jasa Pemerintah Di Provinsi Lampung
}

\section{Prevention of Corruption, Collusion and Nepotism in Government Procurement of Goods and Services in Lampung Province}

\author{
M. Gian Tantyo \\ tantyogian@gmail.com
}

Dewan Perwakilan Rakyat Daerah Provinsi Lampung

Submitted: August 14, 2020; Reviewed: Sept 15, 2020; Accepted: Okt 19, 2020

\begin{tabular}{|c|c|}
\hline Info Artikel & Abstrak \\
\hline $\begin{array}{l}\text { Kata Kunci: Korupsi; Barang; Jasa. } \\
\text { Keywords: Corruption; Goods; Services . }\end{array}$ & 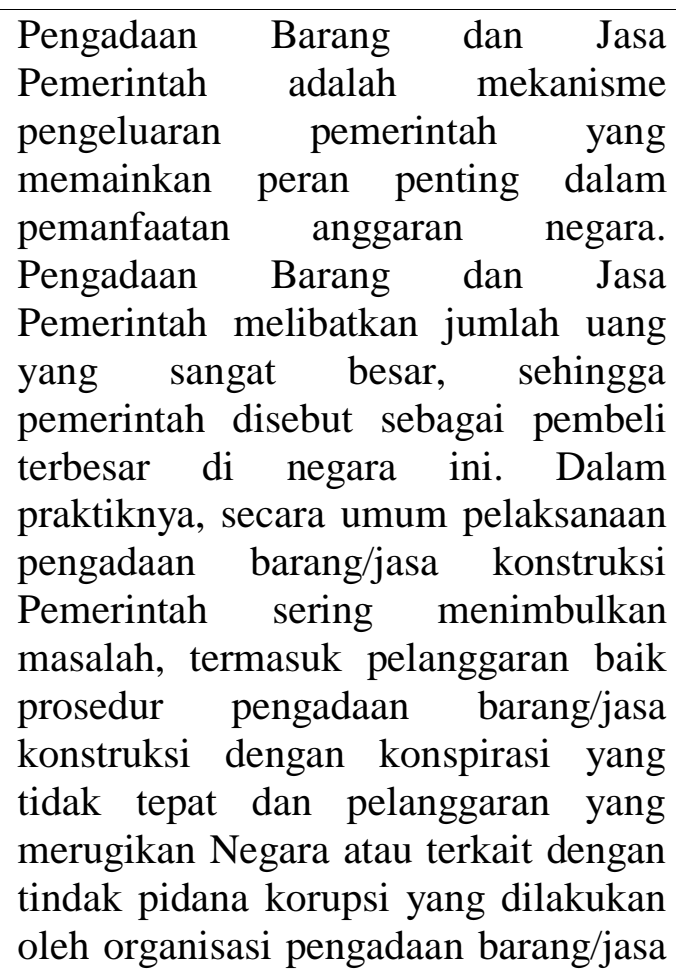 \\
\hline
\end{tabular}

Corruptio is a journal published by Faculty of Law, Universitas Lampung, under a Creative Commons Attribution-ShareAlike 4.0 International License. 
konstruksi. Hasil penelitian ini pada akhirnya memberikan jawaban bahwa penyebab korupsi, kolusi dan nepotisme dalam pengadaan barang dan jasa pemerintah di Provinsi Lampung adalah 1) Dana yang sangat besar dikeluarkan untuk mengubah proyek menjadi penggoda yang kuat untuk mengundang koruptor, 2) Sejumlah besar data ternyata dilengkapi dengan administrasi rencana proyek pemerintah yang tidak jelas dan tertutup. Sedangkan upaya penanggulangan korupsi, kolusi dan nepotisme dalam pengadaan barang dan jasa pemerintah di Provinsi Lampung meliputi: a) Tindakan pencegahan, dalam bentuk: Pengawasan dan Pengadaan Elektronik (E-Procurenment) dan b) Tindakan represif, yaitu: hukum penegakan hukum dengan penerapan sanksi pidana yang ketat. Saran dari penelitian ini adalah bahwa itu harus dirumuskan dengan jelas tentang pertanggungjawaban pidana dalam pelaksanaan pengadaan barang dan jasa pemerintah dari penyedia barang dan jasa serta pada pejabat yang berwenang dalam pelaksanaan pengadaan barang dan jasa pemerintah.

\section{Abstract}

Government Goods and Services Procurement is a government spending mechanism that plays an important role in the utilization of the state budget. Government Goods and Services Procurement involves a very large amount of money, so the government is referred to as the biggest buyer in the country. In practice, in general the implementation of procurement of good / services of Government construction often results in problems, including violations both of the 


\section{procedures for procurement of construction goods/services with improper conspiracy and violations that are detrimental to the State or related to criminal acts of corruption committed by construction goods/service procurement organization.}

The results of this study ultimately provide the answer that the causes of corruption, collusion and nepotism in the procurement of government goods and services in Lampung Province are 1) Very large funds poured out to turn the project into a powerful tempter to invite corruptors, 2) Large amount of data it turned out that it was complemented by the administration of unclear and closed government project plans. While efforts to tackle corruption, collusion and nepotism in the procurement of government goods and services in Lampung Province include: a) Preventive measures, in the form of: Supervision and Electronic Procurement (EProcurenment) and b) Repressive Actions, namely: law enforcement with the application of law strict criminal sanctions.

Suggestion from this research is that it should be formulated clearly about criminal liability in the implementation of government goods and services procurement of goods and services providers as well as on authorized officials in the implementation of government goods and services procurement.

\section{A. Pendahuluan}

Bidang Jasa Konstruksi adalah sebagai salah satu bidang, dalam sarana pembangunan, sudah seharusnya diatur dan dilindungi secara hukum agar terjadi situasi yang objektif dan kondusif dalam pelaksanaannya. ${ }^{1}$ Umumnya, pelaksanaan pengadaan barang dan atau jasa Konstruksi pemerintah, seringkali terjadi permasalahan-permasalahan, antara lain terjadi pelanggaran-pelanggaran baik dari prosedur pengadaan barang/jasa konstruksi dengan

${ }_{1}^{1}$ Adrian Sutedi, Aspek Hukum Pengadaan Barang dan Jasa dan Berbagai Permasalahannya, Jakarta: Sinar Grafika, 2012, hlm. 35 
kerjasama yang tidak baik serta pelanggaran yang sifatnya merugikan Negara atau terkait tindak pidana korupsi yang dilakukan oleh organisasi pengadaan barang/jasa Kontruksi. Pengandaan barang/jasa yaitu mencakup penjelasan dari dari seluruh proses sejak awal perencanaan, persiapan, perijinan, penentuan pemenang lelang hingga tahap pelaksanaan dan proses administrasi dalam pengadaan barang, pekerjaan atau jasa seperti jasa konsultasi teknis, jasa konsultasi keuangan, jasa konsultasi hukum atau jasa lainnya. ${ }^{2}$

Pengandaan barang/jasa pada hakikatnya merupakan upaya pemerintah sebagai pengguna barang/jasa untuk mewujudkan atau mandapatkan barang/jasa yang diinginkan. Dalam pengandaan barang/jasa supaya kebutuhan akan barang/jasa terpenuhi dengan baik sesuai dengan kamampuan keuangan negara yang terbatas, maka pemerintah perlu mengatur norma, prinsip-prinsip, metode dan proses pengandaan barang/jasa. ${ }^{3}$ Pengandaan barang/jasa harus dapat dilaksanakan seacara efektif dan efesian serta dapat dipertanggungjawabakan, karena potensi kerugian negara sangat besar dalam proses pengandaan ini. ${ }^{4}$ Namun, dalam pelaksanaan pengadaan barang/jasa pemerintah sering kali tidak berjalan sesuai dengan mekanisme pengadaan barang/jasa yang ditetapkan pemerintah. ${ }^{5}$

Pemerintah menyediakan anggaran dalam jumlah yang sangat besar untuk pengadaan barang/jasa untuk menunjang pembangunan nasional. Pengadaan barang/jasa pemerintah tidak terlepas dari upaya pemerintah untuk mensejahterahkan masyarakat yang dilaksanakan dengan memanfaatkan keuangan negara yang jumlahnya terbatas, maka dilaksanakan dengan efektif dan efisien agar dapat diperoleh barang/jasa yang jenis, model dan tipenya sesuai dengan kebutuhan sehingga memberikan manfaat yang maksimal bagi peningkatan kinerja pemerintah dan kesejahteraan masyarakat, dengan memanfaatkan sumber dana yang ada sehemat mungkin dan bebas dari segala bentuk kebocoran dan pemborosan.

Namun, seringkali pada pengadaan barang/jasa pemerintah ini kerap terjadinya praktek Korupsi, Kolusi dan Nepotisme (KKN). Banyaknya korupsi dan penyimpangan dalam penyelenggaraan negara merupakan suatu tantangan tersendiri bagi negara ini. Menyiapkan strategi "perang" membasmi korupsi di Indonesia tidaklah semudah yang dibayangkan dalam kiat-kiat praktis administrasi pemerintahan. ${ }^{6}$ Korupsi di Indonesia merupakan suatu permasalahan yang sudah sangat parah, yang tidak mudah untuk dihapuskan karena sudah terlalu mengakar di bangsa Indonesia. ${ }^{7}$ Korupsi tidak pernah lepas dari interaksi kekuasaan, dalam menjalankan suatu amanah seringkali para koruptor tidak memperhatikan etika profesi maupun moral dalam menjalakan amanah yang di embannya. ${ }^{8}$ Sebab korupsi juga sering terjadi pada elemen-elemen pemerintahan dalam hal penyalahgunaan kekuasaan dalam bidang politik, ekonomi, dan sosial-masyarakat dalam berbagai cara dan bertindak, hukum berperan

\footnotetext{
2 Arindra Rossita Arum Nurchana, Bambang Santoso Haryono \& Romula Adiono, "Efektivitas E-Procurement Dalam Pengadaan Barang/Jasa (Studi Terhadap Penerapan E-Procurement Dalam Pengadaan Barang/Jasa Di Kabupaten Bojonegoro)." Jurnal Administrasi Publik. Vol. 2. No.2 (2014).

${ }^{3}$ Dwi Haryati, Anugrah Anditya \& Richo Andi Wibowo. "Pelaksanaan Pengadaan Barang/Jasa Secara Elektronik (EProcurement) Pada Pemerintah Kota Yogyakarta.” Jurnal Mimbar Hukum. Vol.23. No. 2. (2011).

${ }^{4}$ Apri Liatiyanto, "Pembaharuan Regulasi Pengandaan Barng dan Jasa Pemerintah." Jurnal Rechtsvinding. Vol. 1. No. 1 (2012).

${ }^{5}$ Ibsaini \& Mahdi Syahbandir, "Pertanggungjawaban Korporasi Dalam Tindak Pidana Korupsi Pengadaan Barang Dan Jasa Pemerintah (Suatu Penelitian Di Wilayah Hukum Pengadilan Tipikor Banda Aceh)." Legitimasi: Jurnal Ilmu Hukum Pidana Dan Politik Hukum. Vol. 7. No. 1 (2018).

${ }^{6}$ Muhammad Insa Ansari, "Penerapan Pakta Integritas Pada Pengadaan Barang/Jasa Untuk Mewujudkan Tata Kelola Pemerintah Yang Bersih.” Kanun Jurnal Ilmu Hukum. Vol.18. No. 13. (2016).

${ }^{7}$ Arizon Mega Jaya, "Implementasi Perampasan Harta Kekayaan Pelaku Tindak Pidana Korupsi.” Jurnal Cepalo. Vol. 1. No. 1 (2017). hlm. 22.

${ }^{8}$ Imadah Thoyyibah, "Makna Kejahatan Struktural Korupsi Dalam Perspektif Teori Strukturasi Anthony Giddens.” Jurnal Filsafat Universitas Gadjah Mada. Vol. 25. No.1 (2015).
} 
sebagai instrumen penting dalam menciptakan suatu kondisi yang stabil dalam penyelenggaraan Neagra. ${ }^{9}$

Selain masalah korupsi juga terdapat permasalahan lain seperti Kolusi. Kolusi (collusion) adalah tindakan persekongkolan, persekutuan, atau permufakatan untuk urusan yang tidak baik. Sedangkan menurut Pasal 1 Ayat (4) Undang-Undang No. 28 Tahun 1999 tentang Penyelenggara Negara Yang Bersih dan Bebas Korupsi, Kolusi, dan Nepotisme, kolusi diartikan sebagai permufakatan atau kerjasama secara melawan hukum antar Penyelenggara Negara atau antara Penyelenggara Negara dan pihak lain yang merugikan orang lain, masyarakat, dan atau Negara. Korupsi, Kolusi, dan Nepotisme (KKN) akhir-akhir ini dianggap sebagai wujud paling buruk dan paling ganas dari gejala kemerosotan moral dari kehidupan masyarakat dan bernegara di negeri kita. KKN adalah produk dari relasi sosialpolitik dan ekonomi yang pincang dan tidak manusiawi. ${ }^{10}$

Penyaluran dan pendistribusian anggaran belanja negara salah satunya melalui pengadaan barang/jasa pemerintah, dalam pengadaan barang/jasa pemerintah tidak terlepas dari upaya pemerintah untuk mensejahterahkan masyarakat yang dilaksanakan dengan memanfaatkan keuangan negara yang jumlahnya terbatas, maka dilaksanakan dengan efektif dan efisien agar dapat diperoleh barang/jasa yang jenis, model dan tipenya sesuai dengan kebutuhan sehingga memberikan manfaat yang maksimal bagi peningkatan kinerja pemerintah dan kesejahteraan masyarakat, dengan memanfaatkan sumber dana yang ada sehemat mungkin dan bebas dari segala bentuk kebocoran dan pemborosan. ${ }^{11}$

Pengadaan barang/jasa pemerintah merupakan komponen fundamental dari tata kelola pemerintahan yang baik (good governance). ${ }^{12}$ Bentuk-bentuk dari tindak pidana korupsi yang dilakukan dalam pengadaan barang/jasa konstruksi pun ada bermacam-macam. Sebagaimana halnya kondisi pada provinsi lampung tersendri, dengan giatnya pemerintah daerah provinsi lampung terhadap pembangunan kontruksi yang ada saat ini, seperti pembangunan fly over, perbaikan jalan, gorong-gorong dan lain sebagainya. Kegiatan kontruksi tersebut merefleksikan maraknya terjadinya tindak pidana korupsi, kolusi dan nepotisme yang ada di Provinsi Lampung, sebagaimana yang terjadi pada Zainudin (Bupati Lampung Selatan) yang ditangkap tangan oleh KPK karena dugaan kasus korupsi dengan persekongkolan tidak baik, dalam deskripsinya pada rentan waktu Tahun 2016 sampai Tahun 2018, Zainudin menerima uang dari Anggota DPRD Lampung dari Fraksi PAN, Agus Bhakti Nugroho (ABN), yang sumbernya dari proyek-proyek di Dinas Pekerjaan Umum dan Penataan Ruang Kabupaten Lampung Selatan sejumlah Rp57 miliar. Diduga persentase fee proyek dalam 3 Tahun tersebut sekitar 15-17 persen dari nilai proyek. Deskripsi kasus tersebut diatas menunjukan bahwa korupsi dapat terjadi dengan konsep yang berupa peresekongkolan untuk urusan yang tidak baik antara para pihak dan dapat merugikan masyarakat, bangsa dan Negara. Persekongkolan terebut dilakuakn Zainudin dan Agus dengan cara mengatur proyek di Dinas Pekerjaan Umum dan Penataan Ruang Kabupaten Lampung Selatan, yang proyeknya diberikan kepada CV 9 Naga. Berangkat dari deskripsi tersbeut diatas penulis tertarik megkaji serta menganalisis faktor penyebab terjadinya Korupsi, Kolusi Dan Nepotisme Dalam Pengadaan Barang Dan Jasa Pemerintah di Provinsi Lampung serta upaya penanggulangan

\footnotetext{
${ }^{9}$ Jawade Hafidz Dan Agung Widodo, "Pelanggaran Perpres Nomor 54 Tahun 2010 Tentang Pengadaan Barang Dan Jasa Pemerintah Oleh Penyedia Barang Dan Jasa Atau Pengguna Jasa Dalam Perspektif Tindak Pidana Korupsi." Jurnal Pembaharuan Hukum. Vol. 2. No. 2 (2015).

${ }^{10}$ Ismansyah dan Purwantoro Agung Sulistyo, "Permasalahan Korupsi, Kolusi, dan Nepotisme di Daerah serta Strategi Penanggulangannya." Jurnal Demokrasi. Vol. 9. No. 1 (2010).

${ }^{11}$ Tunggul Yohannes Syafruddin Kalo, Sunarmi, Mahmud Mulyadi, “Analisis Tindak Pidana Pencucian Uang Dari Hasil Tindak Pidana Korupsi Terhadap Pengadaan Barang Dan Jasa (Studi Putusan Mahkamah Agung Nomor 1793 K/Pid.Sus/2014)." Usu Law Journal. Vol. 4. No. 3 (2016).

${ }^{12}$ Zaenal Arifin, “Tindak Pidana Korupsi Dalam Proses Pengadaan Barang Dan Jasa Pemerintah.” Jurnal Hukum Responsif. Vol. 5 No. 5 (2017).
} 
terhadap korupsi, kolusi dan nepotisme dalam pengadaan barang dan jasa Pemerintah Di Provinsi Lampung.

\section{B. Pembahasan}

1. Penyebab Terjadinya Korupsi, Kolusi Dan Nepotisme Dalam Pengadaan Barang Dan Jasa Pemerintah di Provinsi Lampung

Penyimpangan pada pelaksanaan pengadaan barang dan jasa pemerintah dilampung dapat dilihat mulai dari tahap awal pengadaan sampai dengan tahap akhir prosedur pelaksanaan pengadaan barang/jasa pemerintah, seperti yang terjadi pada pengadaan barang dan jasa yang dilakukan oleh CV. Gilang 9 Naga, penyimpangan tersebut disebabkan oleh kelalaian dan kompetensi pelaksanaan serta peserta pengadaan, yang mana hal tersebut timbul dikarenakan adanya perbuatan nepotisme yang dilakukan oleh pihak CV. 9 Naga kepada para pemgang kekuasaan seperti Bupati Lampung Selatan Zainudin Hasan dan Petinggi Anggota Dewan Provinsi Lampung. Penyimpangan tersebut merupakan tindakan yang disengaja oleh pelaksana dan/atau peserta pengadaan yang dalam hal ini adalah CV. 9 Naga dengan tujuan menguntungkan/memperkaya diri sendiri atau orang lain yang menjadi mitranya. ${ }^{13}$ Tindakan ini mengakibatkan terjadinya kebocoran/pemborosan uang negara yang begitu besar dan hasil pelaksanaan pengadaan barang/jasa pemerintah yang merupakan salah satu faktor/unsur dalam pelaksanaan pembangunan negara menjadi tidak optimal. ${ }^{14}$

Berdasarkan hasil penelitian yg telah dilakukan oleh penulis, bahwa beberapa bentuk penympangan yang sering terjadi dalam perencanaan pengadaan barang/jasa pemerintah dari tahap perencanaan pengadaan sampai dengan tahap penyerahan barang/jasa adalah sebagai berikut: ${ }^{15}$

a. Tahap Perencanaan Pengadaan

b. Tahap Pembentukan Panitia

c. Tahap Prakualifikasi Peserta

d. Tahap Penentuan Harga Perkiraan Sendiri

e. Tahap Penjelasan Tender (Aanwijzing)

f. Tahap Penyerahan Penaaran dan Pembukaan Penawaran

g. Tahap Evaluasi Penawaran

h. Tahap Pengumman Calon Pemenang

i. Tahap Sanggahan Peserta Lelang

j. Tahap Penunjukan Pemenang

k. Tahap Penandatanganan Kontrak

1. Tahap Penyerahan Barang dan Jasa.

Sejalan dengan beberapa penyimpngan yang sering terjadi dalam perencanaan pengadaan barang/jasa pemerintah dari tahp perencanaan pengadaan sampai dengan tahap penyerahan barang/jasa akan diuraikan tersebut diatas, tahapan prakualifikasi peserta, tahap penyerahan penawaran dan pembukaan penawaran, tahap pengumuman calon pemenang serta tahap penyerahan barang dan jasa adalah merupakan tahapan-tahapan yang dimana para pelaku kolusi, korupsi dan nepotisme di Provinsi Lampung dengan segala caranya melakukan tindak pidana tersebut.

\footnotetext{
13 Arifin Subianto, Kedudukan Pejabat yang Berwenang dalam Pengadaan Barang Dan Jasa Pemerintah Berdasarkan Perpres No. 54 Tahun 2010, Bandung: Citra Aditya Bakti, 2012, hlm. 37

${ }^{14}$ Haris Puerwanto, Beberapa Penyimpangan Prosedu Pelaksana Pengadaan Barang/Jasa Pemerintah, Jakarta: Media Pustaka Ilmu, 2012, hlm. 35.

15 Ali Wisnu Broto, Beberapa Penyimpangan Dalam Pengadaan Barang dan Jasa, Yogyakarta: Universitas Admajaya, 2004, hlm. 72
} 
Penulis yang dalam hal ini mengutip pendapat Jack Bologne (1982), bahwa penyebab kejahatan kolusi, korupsi dan nepotisme dapat di analisis dengan GONE Theory yaitu: ${ }^{16}$

"Greed : adalah keserakahan, kerakuan, pada pelaku. Meraka adalah orangorang yang tidak puas dengan keadaan dirinya.

Opportunity : adalah adanya sistem yang memberi kesempatan atau ruang terjadniya korupsi, antara lain sistme pengendalian yang lemah.

Need

: hal ini berhubungan dengan sikap mental yang tidak pernah cukup, sikap konsumerisme, dan selalu syarat kebutuhan yang tidak pernah usai/tercukupi.

Exposes : berkaitan dengan hkuman pada pelaku yang rendah, sehingga tidak membuat efek jera pada pelaku maupun orang lain (sebagai detterence effect). ${ }^{17}$ ",

Sejalan dengan teori hukum tersebut diatas secara umm, paling tidak ada 3 (tiga) penyebab mudahnya proyek pemerintah di Provinsi Lampung disusupi koruptor, adalah sebagai berikut: ${ }^{18}$

a. Dana sangat besar yang digolotorkan untuk mewujudkan proyek menjadi penggoda yang dahsyat untuk menggundang para koruptor. Penulis melihat bahwa, politik uang yang digunakan oleh para peserta tender pengadaan barang dan jasa pemerintah dalam pemenangan proyek kepada Dinas PU menjadi salah satu penyebab, perbuatan korupsi terjadi sampai pelaksanaan pengadaan barang dan jasa terselesaikan.

b. Jmlah data yang besar tersebut ternyata dilengkapi, dngan pengurusan rencana proyek pemerintah, yang tidak jelas dan tertutup. Penentuan persyarkatan untuk mendapatkan proyek pun berada di genggaman pejabat pemeintah Provinsi Lampung. Kekuasaan untuk menentukan sarat apa yang perlu dibawa oleh calon penawar proyek pemerintah,1 akhirnya dimonopoli sepihak oleh sang pejabat. Sayangnya, kekuasaan dan kewenangan monopoli persyaratan itu tak dijalankan sebagaimana mestinya. ${ }^{19}$

c. Laku koruptif pejabat pengadaan proyek, pemerintah Lampung ternyata di sisi lain bertemu dengan pengusaha hitam atau asosiasi pengusaha buruk. Di sela penjamuan dua pihak tersebut diselipkan juga kepentinggan picik yang saling menguntungkan mereka."

\section{Upaya Penanggulangan Terhadap Korupsi, Kolusi Dan Nepotisme Dalam Pengadaan Barang Dan Jasa Pemerintah Di Provinsi Lampung}

Menarik untuk melirik "berbagai upaya yang dilakukan setiap pimpinan negeri, dalam memberantas korupsi, salah satunya, adalah dengan membuat beberapa formulasi, yg terkait dengan pemberantasan korupsi, namun upaya ini belum menunjukkan hasil yang memuaskan." "Karena formulasi yang dibuat, tidak dibareni dengan daya kerja serta daya paksa yang maksimal." Oleh karena itu, suah menjadi suatu keharusan bagi pemimpi bangsa ini, agar lebih fokus dlam pemberantasan korupsi, sehingga pembangunan di Indonesia dapat erjalan sesuai dengan rencana, yang tentunya akan berdampak pada esejahteraan dan kemakmuran rakyat. ${ }^{20}$ "Salah satu cara yang harus dilakukan pemerintah adalah, dengan

\footnotetext{
${ }^{16} \mathrm{Ibid}$

${ }^{17}$ Muladi \& Dwidja Priyatno, Pertanggungjawaban Pidana Korporasi, Jakarta: Kencana Prenadamedia Group, 2010, hlm. 83

18 Wawancara penulis dengan M. Marwan selaku Kepala Seksi Pidana Umum Kejaksaan Negeri Lampung Tengah, wawancara pada tanggal 18 februari 2019.

${ }^{19}$ Sabrina, Membangun Transparansi, Pengadaan Barang Dan Jasa Melalui Peningkatan Peran ICT Dalam Mereduksi Korupsi, Jurnal Hukum Dan Pembangunan, UGM, Yogyakarta, hlm. 7

${ }^{20}$ Mashuril Anwar, Eddy Rifai, Budi Rizki Husin, "Implementasi Peraturan Jaksa Agung No. 028/A/Ja/10/2014 Tentang Pedoman Penanganan Perkara Pidana Korupsi Dengan Subjek Hukum Korporasi (Studi Pada Kejaksaan Negeri Bandar Lampung)", Jurnal Poenale, Volume 7, hlm. 2
} 
memaksimalkan daya kerja dan daya paksa, dariperaturan perundang-undangan yang ada, melalui penegakan hukum. ${ }^{21}$ Hal ini tentunya bisa berakibat fatal, salah satunya bisa mengancam integritas bangs ini, karena kenyataannya, ketika secara ekonomi kita tidak bisa merdeka dri tekanan-tekanan dari negara yang lebih berkuasa.

Eddy Rifai mengatalan bahwa: "Untuk itu mengimplementasikan Peraturan Presiden pengdaan barang dan jasa instansi pemerintah sudah seharusnya dilakukan. Dngan demikian setiap pengadaan barang dan jasa harus melalui tender terbka dengan melakukan proses penawaran dan tender secara keseluruhan harus dimuat dikoran maupun media elektronik seperti internet, baik untuk, proyek di daerah maupun proyek yang berskala nasional. Upaya penanggulngan korupsi pengadaan barang dan jasa dapat dilakukan dengan dua cara yaitu melalui cara preventif dan represif." 22

1. Penegakan Preventif

Upaya pe,anggulangan dengan metode pencegahan, antara lain:

a) Pengawasan

b) "Pengawaan pengadaan barang dan jasa pemerintah, merupakan tanggung jawab setiap pimpinan dan instansi pemerintah yang terkait pengadaan." Hal tersebut dilakukan agar:

1) Meujudkan aparatur pemerintah yang professional, bersih dan bertanggung jawab.

2) Meminimalisir terjadinya penyalahgunaan wewenang dan praktek korupsi, kolusi dan nepotisme. $^{23}$

Bentuk dari pengawasan diatas, meliputi: pengawasan intern serta pengawasan ekstern. Pengawasan intern adalah, pengawasan yang dilakukan oleh orag yang berada suatu organisasi, yang hasilnya untuk kepentingan organisasi itu juga, sedangkan pengawasan ekstern adalah pengawasan yang diakukan oleh orang/unit yang berada diluar suatu organisasi yang hasilna ditunjukkan kepada pihak yang mempunyai kepentingan dengan organissi tersebut serta dapat juga digunakan oleh organisasi yang bersangkutan. ${ }^{24}$

Salahsatu contoh pengawasan eksternal adalah "pengawasan yang dilakukan oleh masyarakat." Keterlibatan masyarakat sendiri memuat arti ganda, yakni keterlibatan secara luas dan dalam arti sempit. ${ }^{25}$

a) Electronik Procurement (E-Procurement)

"Pratik korupsi, kolusi serta nepotisme, didalam pengadaan barang dan jasa, dilaukan dengan cara tersembunyi, atau berpura-pura melakukan proses yang tranparan, dengan pengaturan orang dalam. Untuk mengatasi hal tersebut, dierlukan proses yang terbuka melalui E-Procurement, atau proses tender dngan cara online, melalui internet yang akan mendapatkan pengawasan dari banyak pihak. E- Procurement sebagai sebuah sistem lelang dalam pengadaan arang oleh pemerintah, dengan sarana teknologi informasi dan komunikasi. Dengan E-Procurement, proses lelang dapat berlangsung efektif dan terbuka. Bersaing dan transparan, adil/tidak diskriminatif, dan akuntabel, sehingga diharapkan dapat meminimalisir raktek curang, dalam proses lelang yang dapat

\footnotetext{
21 "Komisi Pemberantasan Korupsi, Kajian Pencegahan Korupsi Pada Pengadaan Barang dan Jasa Pemerintah, Direktorat Penelitian dan Pengembangan KPK", Jakarta, 2017, hlm. 26

${ }^{22}$ Wawancara penulis dengan Eddy Rifai selaku Dosen Fakultas Hukum, Magister Hukum, Universita Lampung, wawancara pada tanggal 2 Maret 2019.

${ }^{23}$ Putu Diah Trisna Pradana Suari, Eddy Rifai, Budi Rizki Husin, Peran Kpk Dalam Melakukan Operasi Tangkap Tangan Terhadap Pejabat Publik (Studi Wilayah Hukum Lampung Tengah), Jurnal Poenale, Vol. 7, hlm 9

${ }^{24}$ Gusti Ayu Ketut Rachmi, "Korupsi Pengadaan Barang Dan Jasa Pemerintah," Fakultas Hukum Universitas Sebelas Maret, Law Journal, hlm. 8

${ }^{25}$ Eddi Rifai, "Perspektif Pertanggungjawaban Pidana Korporasi Sebagai Pelaku Tindak Pidana Korupsi, 2014, Jurnal Mimbar Hukum-Fakultas Hukum Universitas Gadjah Mada”, Volume 26, Issue 1, hlm. 7
} 
merugikan keunagan negaa. Adapun dasar hukum E-Procurement adalah Pasal 106 dan 107 Perpres No.54 Tahun 2010."

\section{Penegakan Represif}

Yaitu penanggulangan korupsi dengan cara penggunaan sanksi yang tegas, hal tersebut sesuai dengan tujuan hukum pidama: ${ }^{26}$

a. Untuk menakuti setiap orang agar jangan sampai melakukan perbuatan tidak baik.

b. Untuk mendidik orang yang telah pernah melakukan perbuatan yang tidak baik agar menjadi baik dan dapt diterima kembali kedalam kehidupan lingkungannya.

Dalam tindak pidana korupsi, terdapat macam sanksi yang diterapkan. Menurut UndangUndang Nomor 31 Tahun 1999 jo Nomor 20 Tahun 2001, terdapat dua macam sanksi pidana, yang dpat dikenakan terhadap tindak pidana korupsi, yaitu pidana pokok dan pidaa tambahan. Pidana pokok pada Undang-Undang pemberantasan tindak pidaa korupsi ini antara lain:

1) Pidana mati

2) Pidana penjara

3) Pidana denda. ${ }^{27}$

Menurut penulis, "Korupsi semakin mrak terjadi dikarenakan sistem pengawasan yang lemah dan sanksi hukum yang tidak tegas yang berdampak pada tidak adanya efek jera pada para pelku korupsi." "Sebagaimana yang terjadi pada putusan korupsi pengadaan brang dan jasa pemerintah, Nomor 16/PID.SUS.K/2013/PT-MDN, dalam tuutan umum oleh jaksa penuntut umum, yang menjatuhkan pidana terhadp terdakwa Kardius Marlina (KM) berupa pidana penjara selama 7 (tujuh) ahun, dikurangkan selama terdakwa berada dalam tahanan sementara dan pidana denda sebesar Rp. 300.000.000,- (tiga ratus juta rupiah), subsidair4 (empat) bulan kurungan Rp. 1.756.434.566.76,- (satu miliar tujuh ratus lima puluh enam juta empat ratus tiga puluh empat ribu lima ratus enampuluh enam rupiah tujuh puluh enam sen), dengan ketentuan bilamana uang pengganti tersebut tidak dibayarkan, dalam berkekuatan hukum tetap, mka harta bendanya dapat disita dan bilamana harta bendanya tidak mencukupi untuk membayar uang pengganti tersebut maka akan diganti dengan piana penjara selama 3 (tiga) tahun dan 9 (sembilan) bulan, dan dengan perintah terdakwa tetap ditahan.”

Sedangkan dalam putusan hakim pada Putusan Pengadilan Nomor 16/PID.SUS.K/2013/PT-MDN, dalam pertimbangannya, hakim mengadili dan memutus pidana sebagai berikut: Menjatuhkan pidana kepada Terdakwa oleh karena itu dengan pidana penjara selama 4 (empat) tahun dan 6 (enam) bulan dan denda sebesar Rp 200.00.000.- (Dua ratus juta rupiah) dengan ketentuan apabila denda tidak dibayar 4 (empat) bulan.

Menjatuhkan Pidana Tambahan terhdap Terdakwa berupa pembayaran Uang Pengganti sebesar Rp 1.532.453.242,24.- (Satu milyar lima ratus tiga puluh dua juta empat ratus lima puluh tia ribu dua ratus empat puluh dua rupiah dua puluh empat sen), dengan ketentuan jika Terdakwa tidak membayar uang pengganti tersebut dalam waktu1 (satu) bulan setelah putusan memperoleh kekuatan hukum tetap, maka harta bendanya dapat disita oleh Jaksa dan dilelang untuk menutupi uang engganti tersebut, dan dalam hal Terdakwa tidak mempunyai harta benda yang mencukupi untuk membayar uang pengganti tersebut, maka harus diganti dengan pidana penjara selama 2 (dua) tahun.

Sejalan dengan putusan haim tersebut diatas, bahwa pada umumnya hakim dalam mengadili suatu perkara korupsi selalu menjatuhkan hukuman pidana yang dengan dalil

\footnotetext{
${ }^{26}$ Wawancara penulis dengan Hidayat selaku Hakim Pada Pengadilan Negeri Tanjung Karang, wawancara pada tanggal 2 Maret 2019.

${ }^{27}$ Suamrianto Ramlan, “Jenis-Jenis Korupsi daam Pelaksanaan Pengadaan Barang Dan Jasa Pemerintah”, Bandung: Citra Aditya Bakti, 2014, hlm. 1
} 
pertimangannya, menjadi lebih rendah dari apa yang dituntut oleh jaksa penuntut umum pada sistim peradilan tindak pidana korupsi yang ada di Idonesia. Hal tersebut tendesius dengan tidak terberantasnya kejahatan korupsi yang dibuktikan dengan index tindak pidana korupsi yang hingga saaini tidak surut dan serta berdampak kepada makin meningkatnya angka kergian yang diterima oleh Negara.

Secara khusus selamapengawasan dan sistem dalam praktek pengadaan barang dan jasa belum diubah, maka pemberantasa korupsi masih jauh dari yang kita harapkan danselama pengusa termasuk dalam hal ini adalah pejabat pada Pemerintahan Provinsi Lampung masih memberikan peluang kepada para koruptor untukmenggerogoti kekayaan bangsa dan daerah, maka kesejahteraan rakyat dan kejayaan bangsa yang dalam konstitusinya menjadi harapan dan cita-cita angsa ini hanya mimpi belaka.

Problematika tersebut justru sangat memungkinkan munculnya koruptor-koruptor baru. Sebik apapun kebijakan pemerintahan daerah Provinsi Lampung dengan merumuskan suatu peraturan perundang-undangan daerah yang dibuat, akan ttapi kalau tidak disertai dengan kemauan dan tindakan yang tegas dan nyata, maka peraturan tersebut hanya berupa kumpulan peraturan yang tida berarti apa-apa. "Untuk meningkatkan pengawasan dan penegakan Peratuan Daerah, peran serta Pemerintah Daerah Provinsi Lampung, dalam hal ini dengan lembaga pengawasan yang berkopeten dalam pemberantasan tidak pidana korupsi, Kepala daerah, badan legislatif, kepolisian dan kejaksaan dapat membentuk tim pengawas atau komisi pemeriksa."

Peran serta masyarakat sebagaimana dimaksud dalam hal ini adalah peran aktif masyrakat untuk ikut serta mewujudkan pemeritahan yang bersih tetapi harus tetap menaati norma hukum, moral dan sosial yang berlaku dalam masyarakt. Korupsi hanya dapat diberantas apabila ada keinginan kuat dari seluruh lemen masyarakat terutama lembaga penegak hukum sehingga para pelakukorupsi mendapat hukuman yang berat yang memiliki efek jera, dengan demikian seseorang akan takut melakukan tindak pidana korupsi.

\section{Kesimpulan}

Penyebab terjadinya korupsi, kolusi dan nepotisme dalam pengadaan barang dan jasa pemerintah di Provinsi Lampung disebabkan oleh dana besar yang digolontorkan untuk mewujudkan proyek menjadi penggoda yang dahsyat untuk menggundang para koruptor serta jumlah data yang besar tersebut ternyata dilengkapi dengan pengurusan rencana proyek pemerintah yang tidak jelas dan tertutup.

Upaya penanggulangan terhadap korupsi, kolusi dan nepotisme dalam pengadaan barang dan jasa pemerintah di Provinsi Lampung antara lain adalah tindakan preventif, yang berupa pengawasan dan elektronik procurenment (E-Procurenment) serta tindakan represif, yaitu penegakan hukum dengan penerapan sanksi pidana yang tegas.

\section{Daftar Pustaka}

A. Buku

Adrian Sutedi, “Aspek Hukum Pengadaan Barang dan Jasa dan Berbagai Permasalahannya”, Jakarta: Sinar Grafika, 2012.

Ali Wisnu Broto, "Beberapa Penyimpangan Dalam Pengadaan Barang dan Jasa”, Yogyakarta: Universitas Admajaya, 2004.

Arifin Subianto, "Kedudukan Pejabat yang Berwenang dalam Pengadaan Barang Dan Jasa Pemerintah Berdasarkan Perpres No. 54 Tahun 2010", Bandung: Citra Aditya Bakti, 2012.

Haris Puerwanto, "Beberapa Penyimpangan Prosedu Pelaksana Pengadaan Barang/Jasa Pemerintah”, Jakarta: Media Pustaka Ilmu, 2012. 
Komisi Pemberantasan Korupsi, "Kajian Pencegahan Korupsi Pada Pengadaan Barang dan Jasa Pemerintah", Direktorat Penelitian dan Pengembangan KPK, Jakarta, 2017.

Muladi \& Dwidja Priyatno, "Pertanggungjawaban Pidana Korporasi", Jakarta: Kencana Prenadamedia Group, 2010.

Romli Atmasasmita, "Korupsi, Good Governance dan Komisi Anti Korupsi di Indonesia", Jakarta: Badan Pembinaan Hukum Nasional Departemen Kehakiman HAM RI, 2002.

Suamrianto Ramlan, "Jenis-Jenis Korupsi dalam Pelaksanaan Pengadaan Barang Dan Jasa Pemerintah”, Bandung: Citra Aditya Bakti, 2014.

B. Jurnal

Ansari, M. I. "Penerapan Pakta Integritas Pada Pengadaan Barang/Jasa Untuk Mewujudkan Tata Kelola Pemerintah Yang Bersih". Kanun Jurnal Ilmu Hukum. Vol.18. No. 13, 2016.

Arifin, Z. (2017). Tindak Pidana Korupsi Dalam Proses Pengadaan Barang Dan Jasa Pemerintah. Jurnal Hukum Responsif. Vol. 5 No. 5, 2017.

Arindra Rossita Arum Nurchana, B. S. "Efektivitas E-Procurement Dalam Pengadaan Barang/Jasa (Studi Terhadap Penerapan E-Procurement Dalam Pengadaan Barang/Jasa Di Kabupaten Bojonegoro)." Jurnal Administrasi Publik., 2014.

Dwi Haryati, A. A. "Pelaksanaan Pengadaan Barang/Jasa Secara Elektronik (E-Procurement) Pada Pemerintah Kota Yogyakarta." Jurnal Mimbar Hukum. Vol.23. No. 2, 2011.

Gusti Ayu Ketut Rachmi, "Korupsi Pengadaan Barang Dan Jasa Pemerintah", Fakultas Hukum Universitas Sebelas Maret, Law Journal.

Jaya, A. M. "Implementasi Perampasan Harta Kekayaan Pelaku Tindak Pidana Korupsi." Jurnal Cepalo. Vol. 1. No. 1, 2017: 22.

Liatiyanto, A. "Pembaharuan Regulasi Pengandaan Barng dan Jasa Pemerintah." Jurnal Rechtsvinding. Vol. 1. No. 1, 2012.

Mashuril Anwar, Eddy Rifai, Budi Rizki Husin, "Implementasi Peraturan Jaksa Agung No. 028/A/Ja/10/2014 Tentang Pedoman Penanganan Perkara Pidana Korupsi Dengan Subjek Hukum Korporasi (Studi Pada Kejaksaan Negeri Bandar Lampung)”, Jurnal Poenale, Volume 7.

Muhammad Reza Kurniawan, Pujiyono, "Modus Operandi Korupsi Pengadaan Barang dan Jasa Pemerintaholeh PNS", Fakultas Hukum Universitas Diponegoro, Jurnal Law Reform, Vol. 14, No. 1, 2018.

Putu Diah Trisna Pradana Suari, Eddy Rifai, Budi Rizki Husin, "Perspektif Pertanggungjawaban Pidana Korporasi Sebagai Pelaku Tindak Pidana Korupsi." Jurnal Mimbar HukumFakultas Hukum Universitas Gadjah Mada, Vol. 26, Issue 1, 2014.

Sabrina, "Membangun Transparansi, Pengadaan Barang Dan Jasa Melalui Peningkatan Peran ICT Dalam Mereduksi Korupsi”, Jurnal Hukum Dan Pembangunan, UGM, Yogyakarta.

Sulistyo, I. d. "Permasalahan Korupsi, Kolusi, dan Nepotisme di Daerah serta Strategi Penanggulangannya." Jurnal Demokrasi. Vol. 9. No. 1, 2010.

Syahbandir, I. "Pertanggungjawaban Korporasi Dalam Tindak Pidana Korupsi Pengadaan Barang Dan Jasa Pemerintah (Suatu Penelitian Di Wilayah Hukum Pengadilan Tipikor Banda Aceh)." Legitimasi: Jurnal Ilmu Hukum Pidana Dan Politik Hukum..

Thoyyibah, I. "Makna Kejahatan Struktural Korupsi Dalam Perspektif Teori Strukturasi Anthony Giddens." Jurnal Filsafat Universitas Gadjah Mada. Vol. 25. No.1, 2015.

Tunggul Yohannes Syafruddin Kalo, S. M. "Analisis Tindak Pidana Pencucian Uang Dari Hasil Tindak Pidana Korupsi Terhadap Pengadaan Barang Dan Jasa (Studi Putusan Mahkamah Agung Nomor 1793 K/Pid.Sus/2014)." Usu Law Journal. Vol. 4. No. 3.

Widodo, J. H. "Pelanggaran Perpres Nomor 54 Tahun 2010 Tentang Pengadaan Barang Dan Jasa Pemerintah Oleh Penyedia Barang Dan Jasa Atau Pengguna Jasa Dalam Perspektif Tindak Pidana Korupsi." Jurnal Pembaharuan Hukum. Vol. 2. No. 2, 2015. 
